\title{
EFFECTS OF MAIZE (ZEA MAYS L.) INTERCROPPING WITH LEGUMES ON NITROUS OXIDE $\left(\mathrm{N}_{2} \mathrm{O}\right)$ EMISSIONS
}

\author{
CHEN, J. S. ${ }^{1,2 \#}-$ AMIN, A. S. ${ }^{1,2 \#}-$ HAMANI, A. K. M. ${ }^{1,2 \#}-$ WANG, G. S. ${ }^{1}-$ ZHANG, Y. Y. ${ }^{1}-$ \\ $\mathrm{LIU}, \mathrm{K}^{3 *}-\mathrm{GAO}, \mathrm{Y}^{1^{*}}$ \\ ${ }^{1}$ Key Laboratory of Crop Water Use and Regulation, Ministry of Agriculture and Rural \\ Affairs/Institute of Farmland Irrigation, Chinese Academy of Agricultural Sciences, Xinxiang \\ 453002, China \\ ${ }^{2}$ Graduate School of Chinese Academy of Agricultural Sciences, Beijing 10081, China \\ ${ }^{3}$ College of Economics and Management, Shanghai Ocean University, Shanghai 201306, China \\ * Corresponding authors \\ e-mail/phone: gaoyang@caas.cn/+86-373-339-3224; kliu@shou.edu.cn
}

${ }^{\#}$ These authors contributed equally to this work

(Received $6^{\text {th }}$ Apr 2021; accepted $8^{\text {th }}$ Jul 2021)

\begin{abstract}
To investigate the effects of maize/legume intercropping on soil $\mathrm{N}_{2} \mathrm{O}$ emissions, six treatments were tested in the North China Plain: maize, M120 ( $\mathrm{N}$ application rate $120 \mathrm{~kg} \mathrm{ha}^{-1}$ ); maize, M240 (N application rate $\left.240 \mathrm{~kg} \mathrm{ha}^{-1}\right)$; soybean (Glycine max), SS (120 kg ha-1); maize/soybean intercropping, MS (120 kg ha-1); peanut (Arachis hypogaea), PP (120 kg ha $\left.{ }^{-1}\right)$; and maize/peanut intercropping, MP $\left(120 \mathrm{~kg} \mathrm{ha}^{-1}\right)$. The amounts of inorganic nitrogen for the $0-20 \mathrm{~cm}$ soil in MS were $24.0 \%, 5.3 \%$, and $29.3 \%$ lower than in SS, M120, and M240, respectively $(P<0.05)$. The total $\mathrm{N}_{2} \mathrm{O}$ emissions ranged from $0.41 \pm 0.09$ to $0.98 \pm 0.14 \mathrm{~kg} \mathrm{ha}^{-1}$. MP and MS were statistically different at the $95 \%$ confidence level, whereas MP produced the least $\mathrm{N}_{2} \mathrm{O}$ emissions at $0.41 \mathrm{~kg} \mathrm{ha}^{-1}$. The seasonal cumulative $\mathrm{N}_{2} \mathrm{O}$ emissions and global warming potential in MS and MP were also significantly lower than those in the other three monoculture treatments $(P<0.001)$. The results demonstrated that maize/legume intercropping can increase the $\mathrm{N}$ uptake of crops and reduce the amount of soil inorganic nitrogen and $\mathrm{N}_{2} \mathrm{O}$ emissions, thereby, ensuring the sustainability of the agricultural environment.
\end{abstract}

Keywords: soybean, peanut, global warming potential, nitrogen rate, cumulative $\mathrm{N}_{2} \mathrm{O}$ emissions

\section{Introduction}

Nitrous oxide $\left(\mathrm{N}_{2} \mathrm{O}\right)$ emissions are essentially derived from the microbial processes of nitrification and denitrification (Kweku et al., 2018). These processes can be influenced by agricultural management practices, such as fertigation, tillage, crop rotation, and cropping systems (Hénault et al., 2012; Nath et al., 2017; Perdomo et al., 2009). Various cropping patterns are being trialed in the North China Plain to reduce $\mathrm{N}_{2} \mathrm{O}$ emissions with maize/legume intercropping proving to be promising (Huang et al., 2014). Intercropping prairie cordgrass with Kura clover was shown to effectively reduce fertilizer-derived $\mathrm{N}_{2} \mathrm{O}$ emissions and the net global warming potential (Abagandura et al., 2020). A similar suggestion was reported by Senbayram et al. (2016) from intercropping wheat with legumes in Gottingen, Germany. However, global information on the effect of intercropping on $\mathrm{N}_{2} \mathrm{O}$ emissions is quite limited.

The presence of nitrogen in the soil through applied fertilizer is the main reason for the increase of $\mathrm{N}_{2} \mathrm{O}$ emissions from farmlands (Liu et al., 2019). Therefore, improving the nitrogen use efficiency is an effective method of reducing greenhouse gas emissions. 
A large number of studies have shown that intercropping can effectively improve the nitrogen use efficiency of the intercropped populations (Yong et al., 2018), increase the nitrogen uptake of crops ( $\mathrm{Li}$ et al., 2011), and reduce the $\mathrm{N}_{2} \mathrm{O}$ emissions ( $\mathrm{Yu}$ et al., 2019). Studies have shown that the yield of maize/soybean intercropping systems is higher than that of monocultures (Gao et al., 2010; Seran and Brintha, 2010).

Currently, the majority of the intercropping studies focus on interspecific complementarity and competition for nutrients (Gao et al., 2010; Seran and Brintha, 2010), the nitrogen among crop species within intercropping patterns (Qiu et al., 2019), and how to improve the system yield and land equivalent ratio (Dariush et al., 2006). Many studies focused on achieving high yield and high efficiency of crops with only limited information regarding the importance of intercropping techniques for the mitigation of greenhouse gas emissions being reported (Dyer et al., 2012). Although there have been research results on greenhouse gas emissions from intercropping systems, the results are not consistent due to different intercropping patterns and sampling methods.

Few works have reported a relationship between soil $\mathrm{N}_{2} \mathrm{O}$ emissions and different intercropping systems. A unique study by Dyer et al. (2012) indicated that, with regard to greenhouse gas (GHG) emissions, both $\mathrm{CO}_{2}$ and $\mathrm{N}_{2} \mathrm{O}$ showed a general trend of greater emission rates in the maize sole crop followed by the soybean sole crop and were the lowest in the intercrops. Thus, intercropping in Pampa, Argentina could be a more sustainable agroecosystem and land management practice. This was the first study to evaluate soil $\mathrm{N}_{2} \mathrm{O}$ emissions from a temperate maize/soybean intercropping system.

Intercropping treatments of different varieties of barley and pea also showed the ability to significantly reduce $\mathrm{N}_{2} \mathrm{O}$ emissions (Pappa et al., 2011). These studies, and that of Huang et al. (2014), which was conducted in the North China Plain, indicated that intercropping treatments (involving maize and different legumes) could be useful in controlling the $\mathrm{N}_{2} \mathrm{O}$ emissions from soils in different agricultural ecosystems. However, some studies showed that maize/legume intercropping had no significant effect on soil $\mathrm{N}_{2} \mathrm{O}$ emissions. Vachon (2008) showed that there was no significant difference in the soil $\mathrm{N}_{2} \mathrm{O}$ cumulative emissions between corn/soybean intercropping at 1:2 and 2:3 and their single cropping system.

The research on the effect of maize/legume intercropping on $\mathrm{N}_{2} \mathrm{O}$ emissions is not sufficient, and the influence mechanism is not clear, and little attention has been paid to the difference of $\mathrm{N}_{2} \mathrm{O}$ emissions on the intercropping of maize with different legumes. The objective of this work was to evaluate the effects of maize/legume intercropping on $\mathrm{N}_{2} \mathrm{O}$ emissions. The results will aid the development of maize/legume intercropping systems for the mitigation of greenhouse gas emissions and the sustainability of agriculture.

\section{Materials and methods}

\section{Study area}

The experiment was conducted at the Xinxiang Comprehensive Experimental Station $\left(\mathrm{N} 35^{\circ} 14^{\prime}\right.$, E113 $76^{\prime}$, altitude $74 \mathrm{~m}$ ) of the Chinese Academy of Agricultural Sciences from June to September 2018. The site is located in Qiliying Town, Xinxiang County, Xinxiang City, Henan Province. The station is at the Yellow River Irrigation Diversion Area of Renminshengli Canal in the west of the central part of the Huang-Huai-Hai Plain. This location belongs to the warm temperate continental monsoon climate. The 
sunshine duration was $2399 \mathrm{~h}$, the annual average temperature was $14{ }^{\circ} \mathrm{C}$, the annual average rainfall was $582 \mathrm{~mm}$, the rainfall from June to September in 2018 was $357.4 \mathrm{~mm}$, the maximum temperature was $39.6^{\circ} \mathrm{C}$, the minimum temperature was $8.8^{\circ} \mathrm{C}$, and the average temperature was $28.4^{\circ} \mathrm{C}$.

The temperature and rainfall during the study period are shown in Figure 1. The class of the soil was sandy loam (4.52\% clay, $40.27 \%$ silt, $55.21 \%$ sand) according to world soil resources reference base, the parent material of soil was the sediment after the Yellow River alluvial, and the groundwater depth was more than $5 \mathrm{~m}$ ( $\mathrm{Si}$ et al., 2020). The physical and chemical properties of the soil layer $(0-20 \mathrm{~cm})$ of the experimental field are shown in Table 1. Before sowing, the total nitrogen of the 0 $100 \mathrm{~cm}$ soil was $0.9 \mathrm{~g} \mathrm{~kg}^{-1}$, and the inorganic nitrogen reserves of the $0-100 \mathrm{~cm}$ soil were $244.58 \mathrm{~kg} \mathrm{ha}^{-1}$.

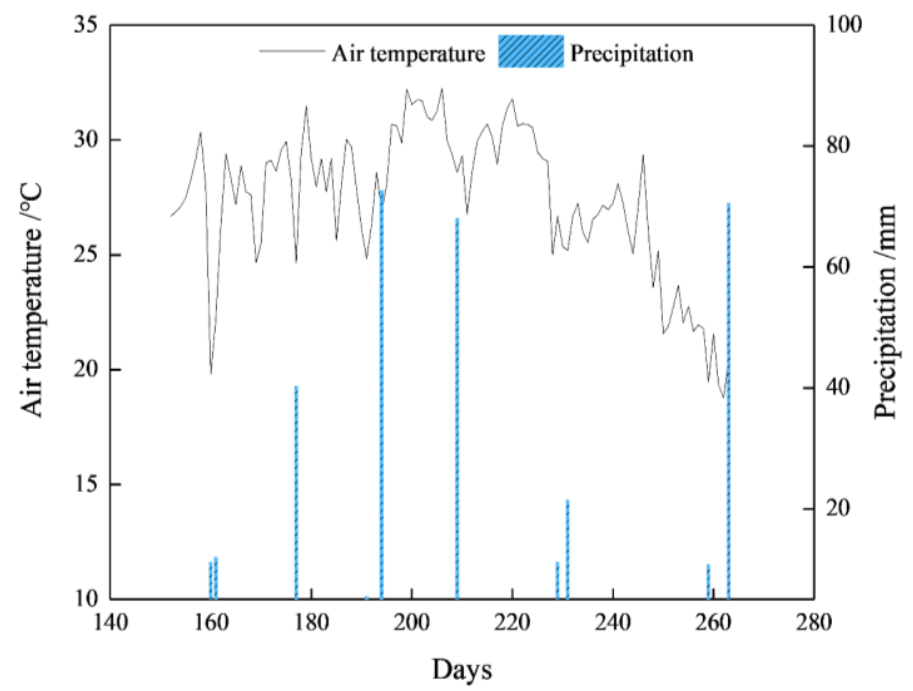

Figure 1. Air temperature and rainfall during the trial period in 2018

Table 1. Soil parameters of the soil at the experimental site

\begin{tabular}{|c|c|c|c|c|c|c|c|}
\hline pH & $\begin{array}{c}\text { Organic } \\
\text { matter } \\
\left(\mathrm{g} \cdot \mathrm{kg}^{-1}\right) \\
\end{array}$ & $\begin{array}{c}\text { Bulk density } \\
\left(\mathrm{g} \cdot \mathrm{cm}^{-3}\right)\end{array}$ & $\begin{array}{c}\text { Alkali-hydrolyzed } \\
\text { nitrogen content } \\
\left(\mathbf{m g} \cdot \mathbf{k g}^{-1}\right)\end{array}$ & $\begin{array}{c}\text { Available K } \\
\text { content } \\
\left(\mathbf{m g} \cdot \mathbf{k g}^{-1}\right) \\
\end{array}$ & $\begin{array}{c}\text { Available } P \\
\text { content } \\
\left(\mathbf{m g} \cdot \mathbf{k g}^{-1}\right) \\
\end{array}$ & $\begin{array}{c}\text { Total nitrogen } \\
\quad\left(\mathrm{g}^{\prime} \mathbf{k g}^{-1}\right)\end{array}$ & $\begin{array}{r}\text { Mineral } \\
\text { nitrogen } \\
\left(\mathbf{m g} \cdot \mathbf{k g}^{-1}\right)\end{array}$ \\
\hline 8.7 & 14.4 & 1.51 & 90.7 & 125.9 & 25.7 & 0.9 & 30.2 \\
\hline
\end{tabular}

\section{Experimental design}

The experiment consisted of six treatments laid in a Randomized Complete Block Design (RCBD) with three replications. The maize monoculture (M240) treatment with nitrogen (urea) application had a standard rate of $240 \mathrm{~kg} \mathrm{ha}^{-1}$. Other treatments included a soybean monoculture (SS), peanut monoculture (PP), maize/peanut intercropping (MP), and maize/soybean intercropping (MS), which received nitrogen (urea) at the rate of $120 \mathrm{~kg} \mathrm{ha}^{-1}$ considering the potential of legumes for complementing nitrogen supply through fixation (Huang et al., 2014).

To compare and analyze the difference in the $\mathrm{N}_{2} \mathrm{O}$ emissions between a monoculture of maize and intercropped population under the same nitrogen application rate, a single cropping of maize with $120 \mathrm{~kg} \mathrm{ha}^{-1}$ nitrogen fertilizer (M120) was also set up (Table 2). 
The maize variety used was "Denghai-605", the peanut variety was "Haihua-1", and the soybean variety was "Jidou-17". Each plot was $7 \mathrm{~m}$ wide and $10 \mathrm{~m}$ long, planted in a north to south orientation. The row spacings applied for maize and legumes monocultures were 60 and $30 \mathrm{~cm}$, respectively. Each hole received two grains at planting. The detailed configuration (showing both row and plant spacings) of the intercropping pattern is as shown in Figure 2.

Table 2. Description of the treatments applied

\begin{tabular}{c|c|c}
\hline Treatment Code & Description & Nitrogen application rate (kg ha-1) \\
\hline M120 & Maize monoculture & 120 \\
M240 & Maize monoculture & 240 \\
SS & Soybean monoculture & 120 \\
PP & Peanut monoculture & 120 \\
MP & Maize/peanut intercropping & 120 \\
MS & Maize/soybean intercropping & 120 \\
\hline
\end{tabular}

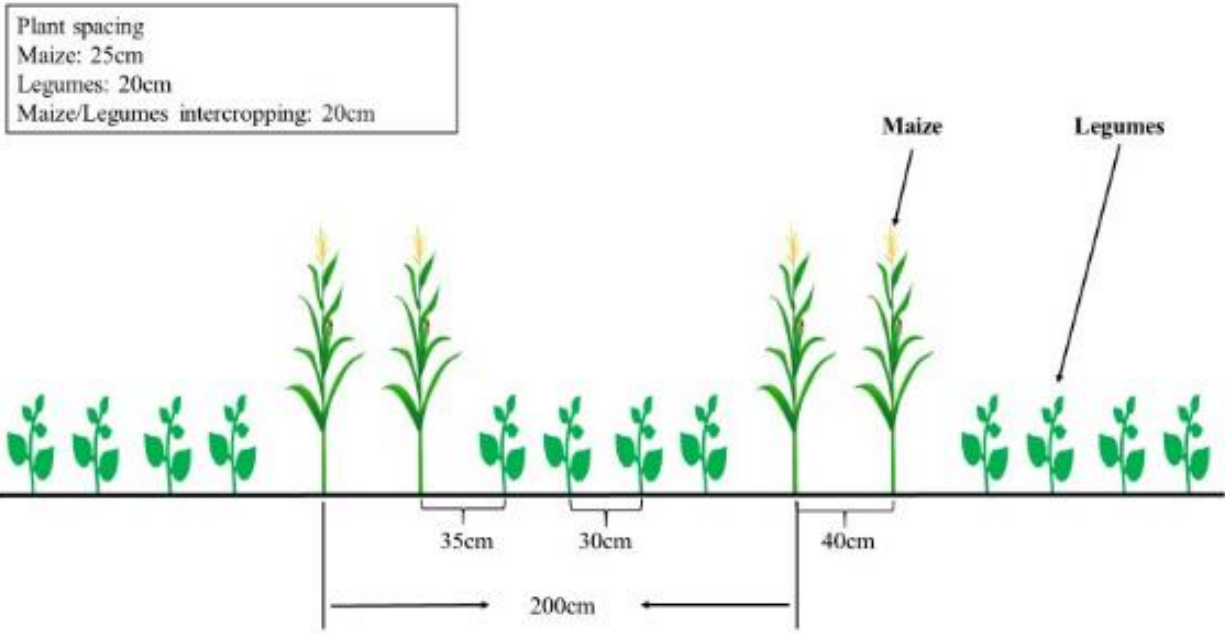

Figure 2. Sketch of the planting patterns

The sowing date of maize, soybean, and peanuts was June 10, 2018, while the harvest was on September 15. Before sowing, the application rates of phosphorus and potassium in all the treatments were the same; $105 \mathrm{~kg} \mathrm{ha}^{-1}$ of $\mathrm{K}_{2} \mathrm{SO}_{4}$ and $120 \mathrm{~kg} \mathrm{ha}^{-1}$ of $\mathrm{P}_{2} \mathrm{O}_{5}$. The nitrogen fertilizer was applied twice with the ratio of base to topdressing of 50:50. The topdressing time was July 12. Irrigation was conducted twice in the whole growth period. The first irrigation date was June 11, and the irrigation method was sprinkler with a quota of $45 \mathrm{~mm}$. The second irrigation date was August 29 when the surface method was used to apply $45 \mathrm{~mm}$.

\section{Sampling and measurement procedures}

Sampling and analysis of $\mathrm{N}_{2} \mathrm{O}$ gas

Nitrous oxide $\left(\mathrm{N}_{2} \mathrm{O}\right)$ samples were taken with a static box and analyzed with gas chromatography (Christiansen et al., 2015). Eleven sampling events were conducted 
during the whole growth period. The size of the static box was length $\times$ width $\times$ height $=100 \mathrm{~cm} \times 50 \mathrm{~cm} \times 10 \mathrm{~cm}$. The static box was made of an acrylic plate with a thickness of $5 \mathrm{~mm}$. The top of the box was open for plant growth and gas sample collection. The static box was sealed and fixed on each sampling point by the soil sealing method (the static box was designed and installed as shown in Figs. 3 and 4).

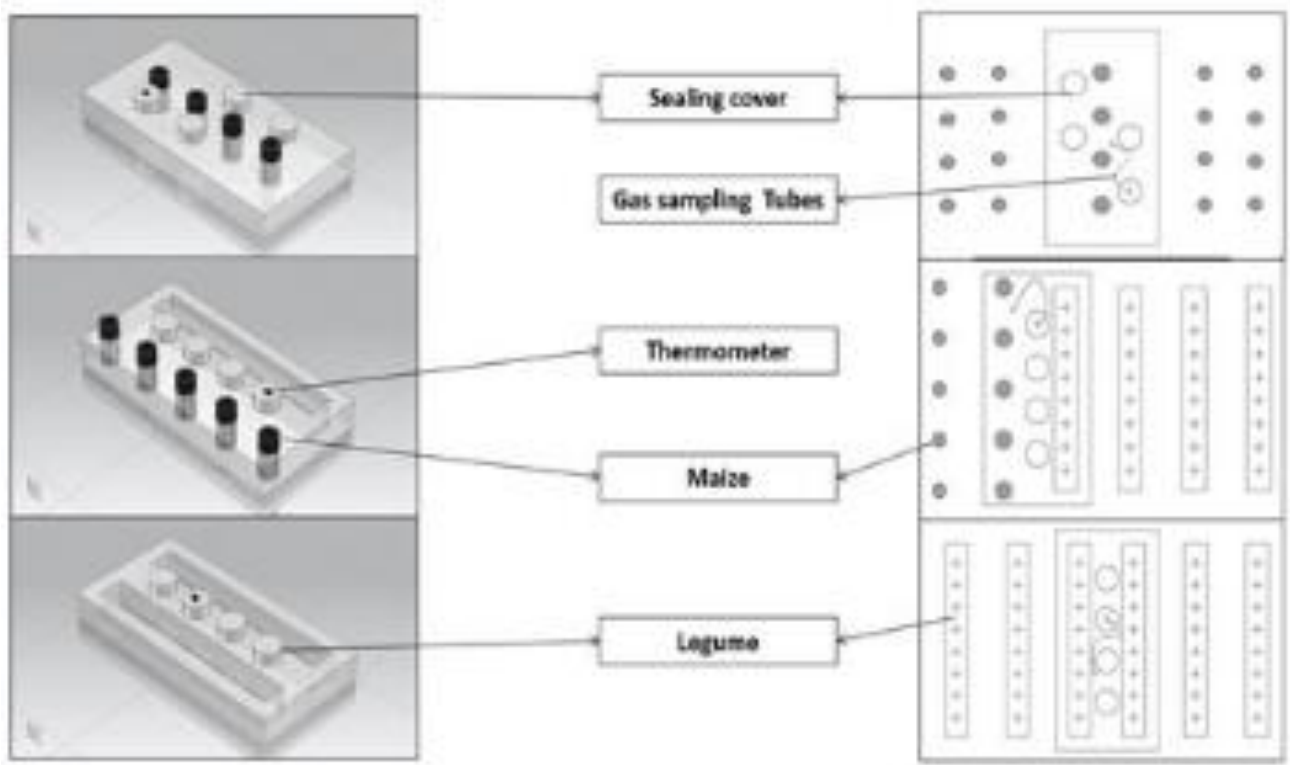

Figure 3. Experimental layout and positioning of the static box

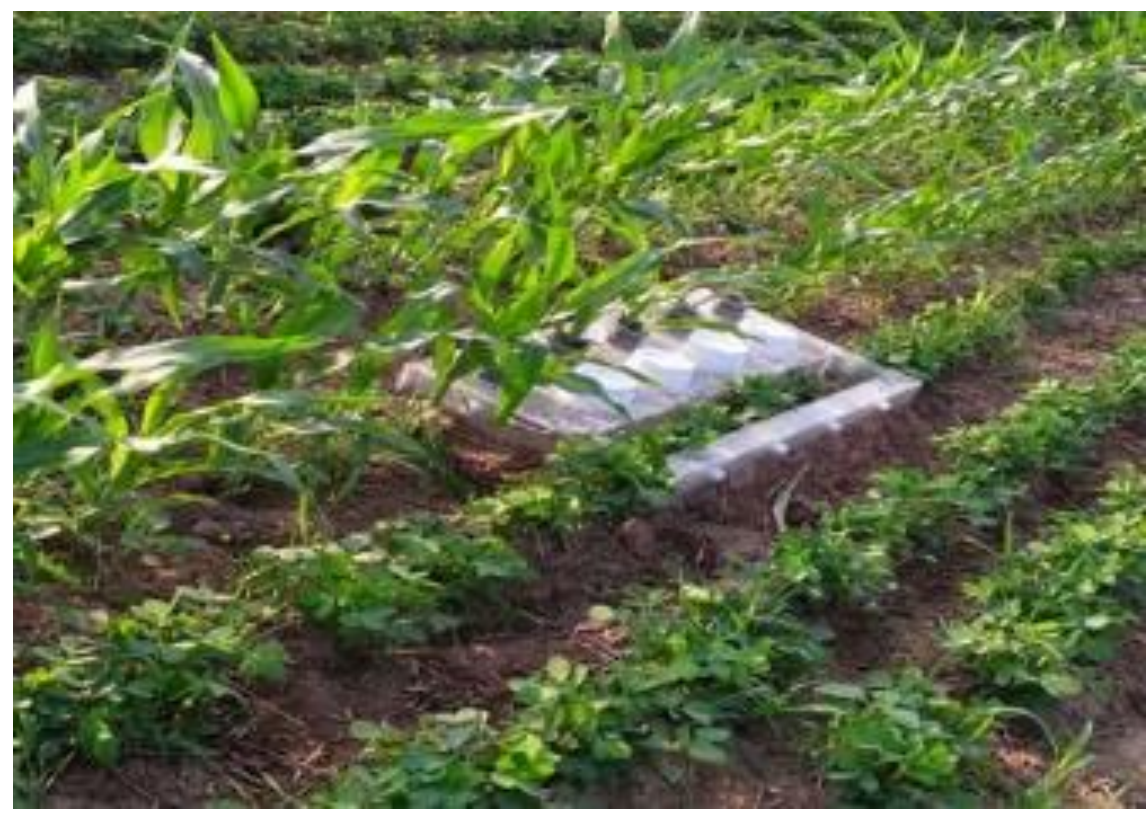

Figure 4. Static box installed at the experimental site

In Figure 3, the left side is the structure diagram of three kinds of static boxes, and the right side shows the orientation of the static box under the three planting styles of single maize, intercrop of maize and legumes, and single legumes. The shaded circles in 
the figure represent Maize and "+" represents soybean or peanuts. Three static boxes were set up in each cell, and the average value of three observations was used. Soil $\mathrm{N}_{2} \mathrm{O}$ gas samples were taken every 7 days starting on June 29 (the seedling stage on the $19^{\text {th }}$ day after sowing) until September 27.

In the event of heavy rainfall, the samples were taken on the third day after rainfall to avoid the peak of $\mathrm{N}_{2} \mathrm{O}$ emission flux caused by the increase of soil water filled porosity (WFPS). The sampling was conducted from 8:00 to 10:00 a.m., and $30 \mathrm{~mL}$ of gas samples (Scheer et al., 2008) were taken at 0, 10, and 20 min after all the covers on the static box were tightened, and the time was recorded with a stopwatch. After sampling, all covers were unscrewed for air circulation in the static box to ensure the normal growth of the crops.

The gas samples collected were analyzed in the laboratory using gas chromatography (model of gas chromatograph: Shimadzu 2010plus). The measuring conditions were as follows: the temperature of the electron capture detector (ECD) detector was $250{ }^{\circ} \mathrm{C}$, the column temperature was $50{ }^{\circ} \mathrm{C}$, the carrier gas was high-purity argon methane gas, and the flow rate was $40 \mathrm{~mL} \mathrm{m^{-1 }}$. The gas emission flux was calculated using Equation 1.

$$
F=\frac{M}{V} \times h \times \frac{d_{c}}{d_{t}} \times \frac{273}{(273+t)}
$$

where $F$ is the emission flux of the gas $\left(\mathrm{mg}\left(\mathrm{m}^{2} \cdot \mathrm{h}\right)^{-1}\right) ; M$ is the molecular weight of the gas $(\mathrm{g}) ; V$ is the volume of $1 \mathrm{~mol}$ gas in the standard state $(\mathrm{L}) ; \mathrm{h}$ is the net height of the sampling box $(\mathrm{m}) ; \frac{d_{c}}{d_{t}}$ is the rate of change of gas concentration in the sampling box, 273 is the gas state path constant, and $t$ is the average temperature in the sampling box $\left({ }^{\circ} \mathrm{C}\right)$.

\section{Soil inorganic nitrogen}

Soil samples were taken from $0-20 \mathrm{~cm}$ to determine the amount of nitrate and ammonium nitrogen. For monocultures, the samples were taken between rows of crops, while for intercropping, the samples were taken between adjacent rows of maize and legume strips, and each sampling point was repeated three times. The fresh soil was extracted with a KCI solution with a concentration of $2 \mathrm{~mol} \mathrm{~L}^{-1}$. The ratio of soil to water was 1:5. The samples were agitated at $200 \mathrm{R} \mathrm{min}^{-1}$ at a constant temperature for $30 \mathrm{~min}$ on an oscillator and then filtered. The collected filtrate was determined using an AA3 flow analyzer (SEAL Analytical) (Anning et al., 2021). The formula used to calculate the soil inorganic nitrogen is as follows:

$$
S I N=d \times B D\left(N_{1}+N_{2}\right)
$$

where SIN is the soil inorganic nitrogen $\left(\mathrm{kg} \mathrm{ha}^{-1}\right) ; d$ is the soil depth, taking $20 \mathrm{~cm}$; BD is the soil bulk density $\left(1.51 \mathrm{~g} \mathrm{~cm}^{-3}\right)$; and $N_{1}$ and $N_{2}$ are nitrate nitrogen and ammonium nitrogen in the $0-20 \mathrm{~cm}$ soil layer, respectively.

\section{Soil water filled porosity}

The moisture content of the soil was measured using the gravimetric method, and the water filled pore space (WFPS) was calculated using Equation 3:

$$
W F P S=\frac{V S W C}{(1-B D / P D)}
$$


where $V S W C$ is the volumetric soil water content (VSWC $=$ soil mass water content $\times$ $B D) ; B D$ was taken as an average value of $1.51 \mathrm{~g} \mathrm{~cm}^{-3}$; and $P D$ is the soil particle density, taking the value of $2.65 \mathrm{~g} \mathrm{~cm}^{-3}$.

\section{Soil temperature}

During gas sampling, the soil temperatures at 0 and $10 \mathrm{~cm}$ were also measured near the static box using a Testo Mini Probe Thermometer, and the average of the two readings was taken.

\section{The cumulative $\mathrm{N}_{2} \mathrm{O}$ emissions and the global warming potential}

The cumulative $\mathrm{N}_{2} \mathrm{O}$ emissions during the whole growth period were estimated using the linear interpolation method as shown in Equation 4:

$$
T N=\sum\left(F_{i+1}+F_{i}\right) / 2 \times\left(t_{i+1}-t_{i}\right) \times 24 \times 10^{-5}
$$

where $T N$ is the total $\mathrm{N}_{2} \mathrm{O}$ emissions in the whole growing season $\left(\mathrm{kg} \mathrm{ha}^{-1}\right) ; F_{i+1}$ is the average $\mathrm{N}_{2} \mathrm{O}$ emission flux of the current experiment $\left(\mu \mathrm{g}\left(\mathrm{m}^{2} \cdot \mathrm{h}\right)^{-1}\right) ; F_{i}$ is the average $\mathrm{N}_{2} \mathrm{O}$ emission flux from the previous experiment $\left(\mu \mathrm{g}\left(\mathrm{m}^{2} \cdot \mathrm{h}\right)^{-1}\right)$; and $\left(t_{i+1}-t_{i}\right)$ is the interval between two successive experiments ( $\mathrm{Li}$ et al., 2013).

Equation 5 was used to calculate the $\mathrm{N}_{2} \mathrm{O}$ based global warming potential (Mehmood et al., 2019):

$$
\operatorname{GWP}\left(\mathrm{N}_{2} \mathrm{O}\right)=\mathrm{TN} \times 265
$$

where $T N$ is the cumulative $\mathrm{N}_{2} \mathrm{O}$ emissions $\left(\mathrm{kg} \mathrm{ha}^{-1}\right)$, and 265 is the global warming potential coefficient for $\mathrm{N}_{2} \mathrm{O}$ (Stocker et al., 2013).

\section{Statistical analysis of data}

The data obtained from the experiments were statistically analyzed by Microsoft Excel, and the significance test was conducted using one-way ANOVA in Spss-23.0 software. The graphs were plotted using Origin Lab software 2018.

\section{Results}

\section{Dynamic change characteristics of the soil moisture and temperature}

Figure 5 shows the variation trend of water filled pore spaces (WFPS) and the soil temperature under different treatments. For the soil moisture, the soil WFPS of each treatment will peak after rainfall or irrigation; however, the WFPS was generally higher in the M120 treatment. The average WFPS in the M120 treatment was significantly higher than that in other treatments, except for M240, which was similar at $(P<0.05)$ (Table 3). In terms of the soil moisture, the average soil WFPS values of maize/legume intercropping (MS) and (MP) were significantly lower than those of monocultures of maize (M120 and M240). However, there was no significant difference in the WFPS between MS and MP nor between PP and SS as shown in Table 3.

For the soil temperature, the trend was similar across treatments; however, the general shape initially rose and then decreased with the crop's growth period. At the end 
of the growth period, the temperature dropped to the lowest level (Fig. 5b). The average soil temperature of the treatments are also shown in Table 3. Generally, there was no significant difference in the soil temperature between intercropping and monocultures.
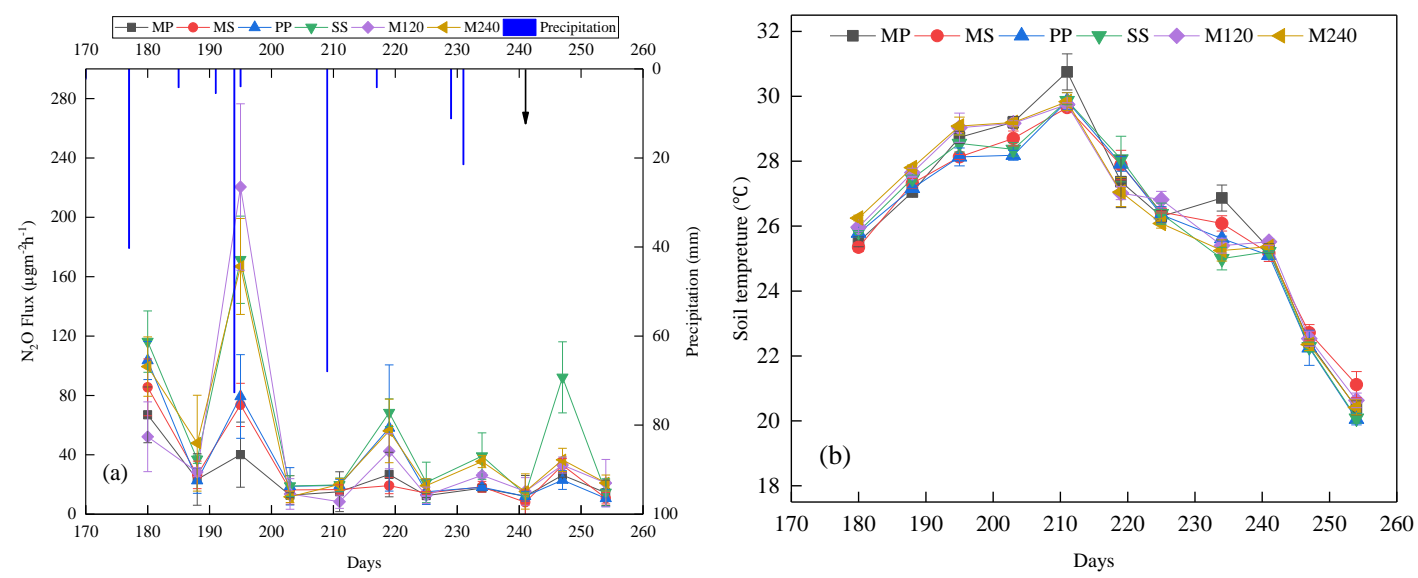

Figure 5. Changes of the (a) water-filled pore space (WFPS) and (b) soil temperature in different treatments. $M P=$ Maize/peanut intercrop, $M S=$ Maize/soybean intercrop, $P P=$ peanut monoculture, $S S=$ Soybean monoculture, $M 120=$ Maize monoculture $(N=120$ $\mathrm{kg} / \mathrm{ha})$, M240 Maize monoculture $(N=240 \mathrm{~kg} / \mathrm{ha})$

Table 3. The cumulative $\mathrm{N}_{2} \mathrm{O}$ emissions, global warming potential, seasonal means of WFPS, temperature $\mathrm{N}-\mathrm{NH}_{4}{ }^{+}, \mathrm{N}-\mathrm{NO}_{3}$, and inorganic- $\mathrm{N}$ of the soils in different treatments during the trial period

\begin{tabular}{|c|c|c|c|c|c|c|c|}
\hline Treatment & $\begin{array}{c}\text { WFPS } \\
(\%)\end{array}$ & $\begin{array}{c}\text { Temperature } \\
\left({ }^{\circ} \mathrm{C}\right)\end{array}$ & $\begin{array}{c}\mathrm{N}-\mathrm{NH}_{4}^{+} \\
\left(\mathrm{mg} \mathrm{kg}^{-1}\right)\end{array}$ & $\begin{array}{c}\mathrm{N}-\mathrm{NO}_{3}^{-} \\
\left(\mathrm{mg} \mathrm{kg}^{-1}\right)\end{array}$ & $\begin{array}{c}\text { SIN } \\
\left(\mathrm{kg} \mathrm{ha}^{-1}\right)\end{array}$ & $\begin{array}{r}T N\left(\mathrm{~N}_{2} \mathrm{O}\right) \\
\left(\mathrm{kg} \mathrm{ha}^{-1}\right)\end{array}$ & $\begin{array}{c}G W P\left(\mathrm{~N}_{2} \mathrm{O}\right) \\
\left(\mathrm{kg} \mathrm{ha}^{-1}\right)\end{array}$ \\
\hline MP & $44.50 \pm 0.99 c$ & $26.35 \pm 0.15 \mathrm{a}$ & $3.25 \pm 0.19 a$ & $7.21 \pm 0.76 b c$ & $31.60 \pm 2.50 \mathrm{bc}$ & $0.41 \pm 0.09 \mathrm{c}$ & $109.63 \pm 23.70 c$ \\
\hline MS & $43.89 \pm 1.33 c$ & $26.23 \pm 0.05 \mathrm{ab}$ & $3.31 \pm 0.09 \mathrm{a}$ & $6.07 \pm 0.77 \mathrm{c}$ & $28.32 \pm 2.60 c$ & $0.50 \pm 0.02 b$ & $132.41 \pm 6.46 b$ \\
\hline $\mathrm{PP}$ & $46.06 \pm 2.51 b c$ & $26.03 \pm 0.04 b$ & $3.20 \pm 0.07 \mathrm{a}$ & $7.70 \pm 1.57 b c$ & $32.90 \pm 4.72 b c$ & $0.59 \pm 0.06 \mathrm{~b}$ & $155.61 \pm 26.16 b$ \\
\hline SS & $45.91 \pm 2.11 b$ & $26.10 \pm 0.07 b$ & $3.36 \pm 0.22 \mathrm{a}$ & $8.98 \pm 1.48 \mathrm{ab}$ & $37.26 \pm 4.68 \mathrm{ab}$ & $0.98 \pm 0.14 \mathrm{a}$ & $260.12 \pm 36.81 \mathrm{a}$ \\
\hline M120 & $51.00 \pm 1.76 \mathrm{a}$ & $26.32 \pm 0.06 \mathrm{a}$ & $3.34 \pm 0.07 \mathrm{a}$ & $6.57 \pm 0.09 c$ & $29.91 \pm 0.29 \mathrm{c}$ & $0.79 \pm 0.11 \mathrm{a}$ & $209.29 \pm 28.96 a$ \\
\hline M240 & $48.80 \pm 2.19 a$ & $26.24 \pm 0.08 \mathrm{a}$ & $2.95 \pm 0.03 b$ & $10.32 \pm 1.09 \mathrm{a}$ & $40.08 \pm 3.30 \mathrm{a}$ & $0.86 \pm 0.21 \mathrm{a}$ & $226.64 \pm 55.85 a$ \\
\hline
\end{tabular}

Different small letters in the same column indicate significant differences at the 0.05 level among treatments

\section{Effects of the different planting patterns on the soil inorganic nitrogen}

Table 3 shows the changes in the WPFS, temperature, ammonium, nitrate, inorganic nitrogen, total emissions, and global warming potential (GWP) within the $0-20 \mathrm{~cm}$ soil for each treatment. There was no significant difference in the amounts of ammonium in the $0-20 \mathrm{~cm}$ soil among treatments with the same amount of nitrogen application. The results of one-way ANOVA showed that the planting patterns had significant effects on the soil nitrate over the whole crop season $(P<0.05)$. The average soil inorganic nitrogen content of the MS treatment was $24.0 \%$ lower than SS, 5.3\% lower than M120, and $29.3 \%$ lower than M240.

On the other hand, the average soil inorganic nitrogen content of the MP and PP treatments were statically similar to M120 but significantly $(P<0.05)$ lower than M240 by $21.1 \%$. The average soil inorganic nitrogen content of the MS treatment was $10.4 \%$ lower than MP, and the average soil nitrate nitrogen content in the MS treatment was $15.9 \%$ lower than MP, although there were not significant differences in both 
parameters. The average soil nitrate nitrogen content in the MS treatment was $32.5 \%$ lower than SS and 41.2\% lower than M240 at a significance level of 95\%. The single factor analysis of variance showed that the planting pattern comparing monocultures and intercropping had a significant effect on the soil nitrate content of $0-20 \mathrm{~cm}$ in the whole growth period $(P<0.05)$.

\section{Effects of different treatments on the soil $\mathrm{N}_{2} \mathrm{O}$ emission flux and global warming potential}

Figure 6 shows the dynamics of the $\mathrm{N}_{2} \mathrm{O}$ emission fluxes. The peak value of $\mathrm{N}_{2} \mathrm{O}$ was as a result of rainfall, which increased the soil WFPS. The graph indicates that the $\mathrm{N}_{2} \mathrm{O}$ emission fluxes of each treatment had a peak value after rainfall. It can also be seen from Table 3 that the average $\mathrm{N}_{2} \mathrm{O}$ emission fluxes of the MS and MP treatments were lower than those of the other four treatments.

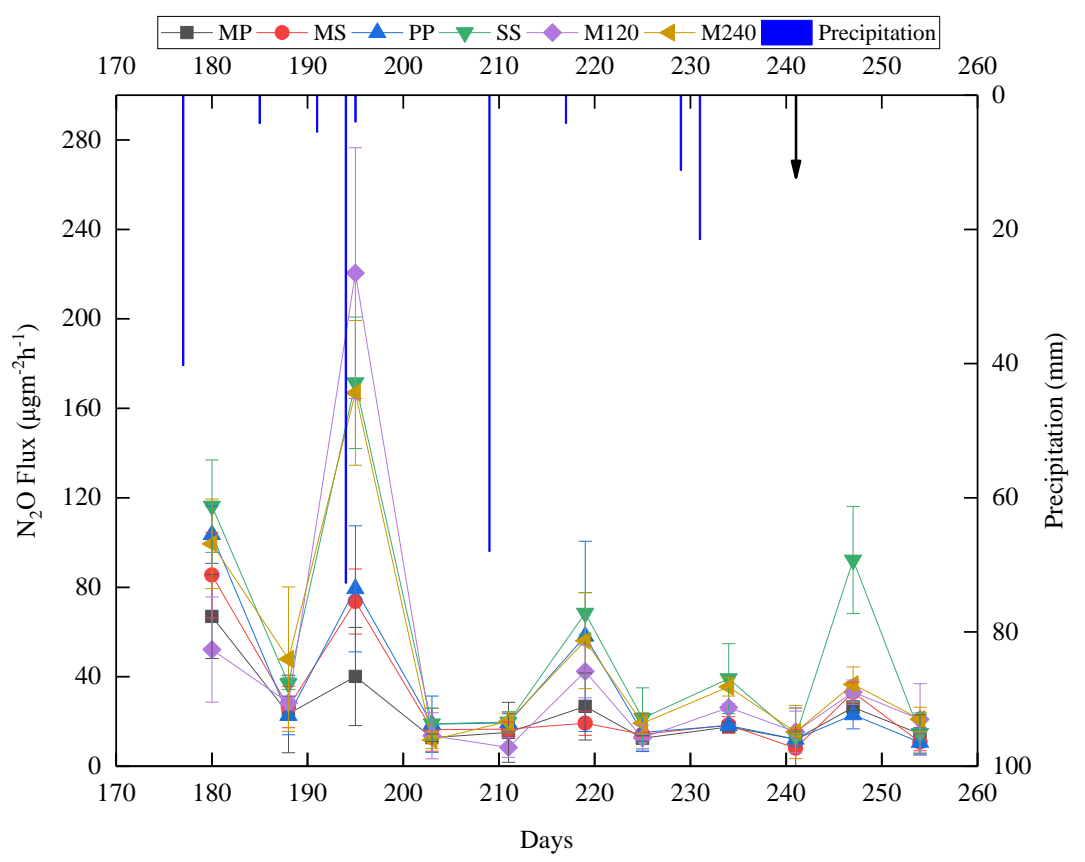

Figure 6. Dynamics of the soil $\mathrm{N}_{2} \mathrm{O}$ emission flux with different treatments. $M P=$ Maize/peanut intercrop, $M S=$ Maize/soybean intercrop, $P P=$ peanut monoculture, $S S=$ Soybean monoculture, M120 = Maize monoculture $(N=120 \mathrm{~kg} / \mathrm{ha})$, M240 = Maize monoculture

$$
(N=240 \mathrm{~kg} / \mathrm{ha})
$$

Compared with M120, M240, and SS, the average $\mathrm{N}_{2} \mathrm{O}$ emission flux of the MS treatment was significantly lower by $32.0 \%, 39.2 \%$, and $47.4 \%$, respectively $(P<0.001)$. Similarly compared with M120, M240, and PP, the $\mathrm{N}_{2} \mathrm{O}$ flux from MP treatments was lower by $43.4 \%, 49.4 \%$, and $29.6 \%$, respectively. These results indicate that maize legume intercropping significantly reduced the $\mathrm{N}_{2} \mathrm{O}$ emission flux of the soil. The difference in the $\mathrm{N}_{2} \mathrm{O}$ emission flux between SS and PP was also significant.

From Table 3, the MS and MP treatments significantly reduced the cumulative $\mathrm{N}_{2} \mathrm{O}$ emissions and global warming potential. The results of one-way ANOVA showed that there were significant differences in the $\mathrm{N}_{2} \mathrm{O}$ emissions and global warming potential between MS, MP, and the other four treatments $(P<0.001)$; however, the differences 
among SS, M120, and M240 were not significant. Compared with M120, M240, and SS, the average cumulative emissions of the MS treatment were lower by $36.7 \%$, $41.6 \%$, and $49.1 \%$, respectively. Compared with M120, M240, and PP, the average cumulative emissions of MS treatment were lower by $47.6 \%, 51.6 \%$, and $29.5 \%$, respectively, and the average cumulative emissions of the MS treatment were $20.8 \%$ higher than MP.

Therefore, the maize legume intercropping modes significantly reduced the cumulative $\mathrm{N}_{2} \mathrm{O}$ emissions and global warming potential compared with the other monocultures. Table 4 presents the Pearson correlation coefficients of soil moisture, inorganic nitrogen, and temperature as they affect the average $\mathrm{N}_{2} \mathrm{O}$ emissions under different treatments. The correlation coefficients of the soil moisture, inorganic nitrogen, and average $\mathrm{N}_{2} \mathrm{O}$ emission flux were different among different treatments; however, they were all positive correlations except for the inorganic nitrogen coefficients in the SS treatment. Additionally, the WFPS showed a consistent significant correlation with $\mathrm{N}_{2} \mathrm{O}$ across all treatments.

Table 4. Pearson correlation analysis between the $\mathrm{N}_{2} \mathrm{O}$, WFPS, soil temperature, and inorganic nitrogen

\begin{tabular}{c|c|c|c}
\hline Treatment & WFPS $(\%)$ & Inorganic $\mathbf{N}\left(\boldsymbol{\mu g} \mathbf{~ m}^{-2} \mathbf{h}^{-1}\right)$ & Temperature $\left({ }^{\circ} \mathbf{C}\right)$ \\
\hline MP & $0.708^{*}$ & $0.740^{* *}$ & $-0.17^{\mathrm{ns}}$ \\
MS & $0.860^{* *}$ & $0.579^{\mathrm{ns}}$ & $0.064^{\mathrm{ns}}$ \\
PP & $0.737^{* *}$ & $0.233^{\mathrm{ns}}$ & $0.254^{\mathrm{ns}}$ \\
SS & $0.860^{* *}$ & $-0.027^{\mathrm{ns}}$ & $0.135^{\mathrm{ns}}$ \\
M120 & $0.664^{*}$ & $0.165^{\mathrm{ns}}$ & $0.262^{\mathrm{ns}}$ \\
M240 & $0.772^{* *}$ & $0.248^{\mathrm{ns}}$ & $0.285^{\mathrm{ns}}$ \\
\hline
\end{tabular}

$*$ Significance $(p<0.05), * *$ significance $(p<0.01)$, and ns $=$ no significance

\section{Discussion}

\section{Effects of intercropping on $\mathrm{N}_{2} \mathrm{O}$ emissions from farmland soil}

Intercropping can improve the yield, land equivalent ratio, and resource utilization efficiency of crop systems (Meng et al., 2016). The research results of Chen et al. (2017) on a wheat/garlic intercropped population showed that intercropping increased the wheat yield, and (Huang et al., 2015) concluded that it could also significantly reduce the $\mathrm{N}_{2} \mathrm{O}$ emissions from farmland soil in the North China Plain, which is consistent with the results of this study. The highest cumulative $\mathrm{N}_{2} \mathrm{O}$ emissions in this study were from the soybean monoculture and maize treatments. The research results of Huang et al. (2019) reported the highest cumulative $\mathrm{N}_{2} \mathrm{O}$ emissions from the monoculture of maize treatment which partly agrees with the results of this work.

This inconsistency in conclusions may be due to differences in the planting density, rate of nitrogen fertilizer applied, soil nutrient content, and crop variety in the soybean monoculture treatments of the two studies. In this study, the planting density of soybeans was higher, and the nitrogen application rate was lower; thus, the nitrogen fixation and nitrogen utilization capacity of the monoculture soybeans were changed, resulting in a difference in the soil $\mathrm{N}_{2} \mathrm{O}$ emissions between the studies.

The authors in Dyer et al. (2012) also concluded that maize/legume intercropping could reduce greenhouse gas emissions from farmland soils. The average $\mathrm{N}_{2} \mathrm{O}$ emission flux of maize/legume intercropping farmland was greater than in the monoculture of 
maize. After a comparative observation, we speculated that this phenomenon may be due to different planting varieties, the planting density, nitrogen use, and the proportion of Gramineae and leguminous crops in the intercropping. Therefore, it is necessary for continuous investigation of different types of intercropping patterns on greenhouse gas emissions to better understand the impacts on the soil carbon and nitrogen dynamics.

Intercropping may change the environmental factors related to soil $\mathrm{N}_{2} \mathrm{O}$ production. In this study, the $\mathrm{N}_{2} \mathrm{O}$ emissions of monoculture systems was 2.39 times that of intercropping, which may be caused by a higher soil moisture in the monocultures. Soil moisture supports the activity of nitrification and denitrification bacteria in the soil, promoting the formation of nitrate and ammonium, consequently, leading to a significant increase in the $\mathrm{N}_{2} \mathrm{O}$ emission rate (Smith et al., 2003). There was a significant and positive correlation between the concentrations of nitrate and ammonium and the $\mathrm{N}_{2} \mathrm{O}$ emission rate (Simojoki and Jaakkola, 2000; Avrahami and Bohannan, 2009). The WFPS of intercropping was significantly lower than that of the maize and soybean monocultures, which may be related to the root distribution of the crops in the intercropping system. The researchers in Gao et al. (2009), in a study of the crop root distribution in a maize/soybean intercropping system, found that most of the roots of maize and soybean were distributed in the 0-30 cm soil layer, and the maize roots in the 16-22 cm soil layer could extend laterally to the inter row of soybean strips.

As a result, the water consumption of monoculture system was much higher than that of intercropping. Therefore, the soil moisture status in the intercropping system was lower than that in the monoculture system, which affects the $\mathrm{N}_{2} \mathrm{O}$ emissions. There was no significant difference in the soil temperature, nitrate nitrogen, ammonium nitrogen, and inorganic nitrogen between maize monocultures and intercropping with $120 \mathrm{~kg} \mathrm{ha}^{-1}$ $\mathrm{N}$ application, and inorganic nitrogen was significantly lower than for the maize monoculture with $240 \mathrm{~kg} \mathrm{ha}^{-1} \mathrm{~N}$ application. The maize monoculture produced higher $\mathrm{N}_{2} \mathrm{O}$ emissions compared with the maize/legume intercropping even the $\mathrm{N}$ application was reduced to $120 \mathrm{~kg} \mathrm{ha}^{-1}$.

\section{Analysis on influencing factors of $\mathrm{N}_{2} \mathrm{O}$ emissions from farmland soil}

It is generally understood that $\mathrm{N}_{2} \mathrm{O}$ is produced in the process of nitrification and denitrification dominated by bacteria (Wunderlin et al., 2012; Zhao et al., 2017). The factors affecting soil microbial activities can directly or indirectly influence the production and emissions of $\mathrm{N}_{2} \mathrm{O}$ gas from agricultural soils. These factors include the soil water filled pore spaces (WFPS), soil $\mathrm{pH}$, electrical conductivity (EC) value, temperature, fertilizer use, farming system, and crop planting type (Tang et al., 2016). Soil moisture contents lower than $97 \%$ to $84 \%$ were found to have the highest correlation with $\mathrm{N}_{2} \mathrm{O}$ emissions (Vejan et al., 2016).

However, the soil WFPS in this study were all lower than $84 \%-86 \%$ indicating that intercropping reduced the soil WFPS, which was a major factor in reducing the $\mathrm{N}_{2} \mathrm{O}$ emission flux. At the end of the growth period, the amount of inorganic nitrogen in the 0-20 cm soil increased, but the $\mathrm{N}_{2} \mathrm{O}$ emission rate decreased. This may be due to the decrease in soil temperature at about $20{ }^{\circ} \mathrm{C}$. The decrease in temperature became the dominant factor affecting $\mathrm{N}_{2} \mathrm{O}$ production, which was verified by Xie and Li (2005). Among the six different treatments in this study, there was no significant difference in the average temperature from the $0-20 \mathrm{~cm}$ soil of the intercropping treatments.

From the results, we deduced that the amount of nitrate nitrogen in the $0-20 \mathrm{~cm}$ soil was greater than that of ammonium nitrogen, indicating that the soil environment within 
the growth period was suitable for nitrification. Inorganic nitrogen is the direct substrate of nitrification-denitrification, and its concentration determines the production and emission process of $\mathrm{N}_{2} \mathrm{O}$ (Bai et al., 2017; Liu et al., 2010). Thus, maize/legume intercropping significantly reduced the production and emissions of soil $\mathrm{N}_{2} \mathrm{O}$ by reducing the level of soil inorganic nitrogen. From this study, there were significant differences found in the $\mathrm{N}_{2} \mathrm{O}$ emissions between maize/peanuts and maize/soybeans.

The average cumulative emissions of the MS treatment were $20.8 \%$ higher than MP. However, there were no significant differences in the soil WFPS, inorganic nitrogen, or temperature between MS and MP. Therefore, the difference in gas emissions may be due to the variations in the rhizosphere microbial community caused by different crop species, which will affect the activity of the nitrification and denitrification bacteria (Vejan et al., 2016).

A study by Chen et al. (2018) found that maize/peanut intercropping increased the number of microflora involved in the nitrogen cycle, sulfur cycle, and other beneficial bacteria in the rhizosphere. These microflora promote more of the decomposition and reuse of carbohydrates in the maize/peanut treatments. The researchers also observed a significant reduction in the copies of various genes for denitrification. Similarly, Subbarao et al. (2012) reported that peanut plants released phytochemicals from the roots to inhibit the activities of soil nitrifying microorganisms. Therefore, the difference in the $\mathrm{N}_{2} \mathrm{O}$ emissions between MS and MP in the current study is indicative of these findings.

In this study, we focused on the differences in $\mathrm{N}_{2} \mathrm{O}$ emissions from cropland soils caused by cropping patterns. The main reason is that intercropping can change the micro-environment of a crop-soil system. Compared with a monoculture, intercropping can significantly affect the composition of the crop-root soil bacterial community, promote soil enzyme activity, and improve the soil nutrient utilization rate (Chen et al., 2018).

We also demonstrated that the intercropping mode had a significant effect on the soil water and heat status. The synergistic utilization of nitrogen in a crop system with the intercropping of cereal and legumes is an important approach to realizing highefficiency in the utilization of nitrogen (Wang, 2015). Compared with monocultures, maize/legume intercropping improved the nitrogen uptake (Du et al., 2018; Dwivedi et al., 2015), thus, reducing the amount of inorganic nitrogen in the soil, forming a basis for reducing the $\mathrm{N}_{2} \mathrm{O}$ emissions from farmland.

\section{Conclusion}

The results of this study revealed the contribution of legume intercropping with maize in the reduction of the environmental risks associated with the emissions of $\mathrm{N}_{2} \mathrm{O}$. This understanding will be helpful in ensuring the sustainable production of maize in the study area. Maize intercropping with a legume (peanut or soybean) significantly reduced the cumulative emissions of $\mathrm{N}_{2} \mathrm{O}$ compared to the sole cropping of maize, peanuts, or soybeans.

The lowest cumulative emissions of $0.41 \mathrm{~kg} \mathrm{ha}^{-1}$ were observed in the maize/peanut (MP) treatment, and this was significantly lower than the emissions of maize/soybean (MS). This is despite the fact that the WPFS, inorganic minerals, and nitrate were similar in both the MP and MS treatments. The difference could be attributed to the biological effects of peanut roots on nitrifying bacteria. As our study did not measure 
the mechanisms of the microbial community in the production of $\mathrm{N}_{2} \mathrm{O}$, this is suggested for further investigations of the best intercropping combinations to achieve higher sustainability in crop production.

Acknowledgements. Support from labors of the experimental research station of Farmland Irrigation Research Institute of Chinese Academy of Agricultural Sciences, Research team, the Key Laboratory of Crop Water Use and Regulation, Ministry of Agriculture and Rural Affairs/Institute of Farmland Irrigation, Chinese Academy of Agricultural Sciences is gratefully acknowledged. The Authors would like to express appreciation the National Natural Science Foundation of China (NO. 51879267), and the Agricultural Science and Technology Innovation Program (ASTIP), Chinese Academy of Agricultural Sciences.

Conflict of interests: The authors declare no conflict of interests.

\section{REFERENCES}

[1] Abagandura, G. O., et al. (2020): Intercropping kura clover with prairie cordgrass mitigates soil greenhouse gas fluxes. - Scientific Reports 10.

[2] Anning, D. K., et al. (2021). Divergent Accumulation of Microbial Residues and Amino Sugars in Loess Soil after Six Years of Different Inorganic Nitrogen Enrichment Scenarios. - Applied Sciences 11: 13-5788.

[3] Avrahami, S., Bohannan, B. J. M., (2009): $\mathrm{N}_{2} \mathrm{O}$ emission rates in a California meadow soil are influenced by fertilizer level, soil moisture and the community structure of ammonia-oxidizing bacteria. - Global Change Biology 15: 643-655.

[4] Bai, X., et al. (2017): Fertilization affects the emission of $\mathrm{CO}_{2}$ and $\mathrm{N}_{2} \mathrm{O}$ in Hetao irrigation area (in Chinese). - Journal of Irrigation and Drainage 36: 66-70.

[5] Chen, S., et al. (2017): Effects of winter wheat intercropping with garlic on wheat growth, $\mathrm{CH}_{4}$ Flux emissions and evaluation of economic and environmental benefits. Acta Agriculturae Boreali-Occidentalis Sinica 6.

[6] Chen, J., et al. (2018): Shifts in soil microbial community, soil enzymes and crop yield under peanut/maize intercropping with reduced nitrogen levels. - Applied Soil Ecology 124: 327-334.

[7] Christiansen, J. R., et al. (2015): Comparison of $\mathrm{CO}_{2}, \mathrm{CH}_{4}$ and $\mathrm{N}_{2} \mathrm{O}$ soil-atmosphere exchange measured in static chambers with cavity ring-down spectroscopy and gas chromatography. - Agricultural and Forest Meteorology 211-212: 48-57.

[8] Dariush, M., et al. (2006): Assessing the land equivalent ratio (LER) of two corn [Zea mays L.] varieties intercropping at various nitrogen levels in Karaj, Iran. - Journal of Central European Agriculture 7: 359-364.

[9] Du, J.-B., et al. (2018): Maize-soybean strip intercropping: achieved a balance between high productivity and sustainability. - Journal of Integrative Agriculture 17: 747-754.

[10] Dwivedi, A., et al. (2015): Potential role of maize-legume intercropping systems to improve soil fertility status under smallholder farming systems for sustainable agriculture in India. - International Journal of Life Sciences Biotechnology and Pharma Research 4: 145 .

[11] Dyer, L., et al. (2012): Soil carbon dioxide and nitrous oxide emissions during the growing season from temperate maize-soybean intercrops. - Journal of Plant Nutrition and Soil Science 175: 394-400.

[12] Gao, Y., et al. (2009): Root distribution pattern of maize soybean strip intercropping (in Chinese). - Agricultural Research in Arid Area 27: 92-98.

[13] Gao, Y., et al. (2010): Distribution of roots and root length density in a maize/soybean strip intercropping system. - Agricultural Water Management 98: 199-212. 
[14] Hénault, C., et al. (2012): Nitrous oxide emission by agricultural soils: a review of spatial and temporal variability for mitigation. - Pedosphere 22: 426-433.

[15] Huang, J. X., et al. (2014): Soil nitrous oxide emissions under maize-legume intercropping system in the North China plain. - Journal of Integrative Agriculture 13: 1363-1372.

[16] Huang, J. X., et al. (2015): Effect of maize-soybean intercropping on greenhouse gas emission and the assessment of net greenhouse gas balance in North China Plain. Journal of China Agricultural University 20: 66-74.

[17] Huang, J., et al. (2019): Effects of maize-soybean intercropping on nitrous oxide emissions from a silt loam soil in the North China Plain. - Pedosphere 29: 764-772.

[18] Kweku, D., et al. (2018): Greenhouse effect: greenhouse gases and their impact on global warming. - Journal of Scientific Research and Reports 17: 1-9.

[19] Li, C.-J., et al. (2011): Crop nitrogen use and soil mineral nitrogen accumulation under different crop combinations and patterns of strip intercropping in northwest China. Plant and Soil 342: 221-231.

[20] Li, C., et al. (2013): Emissions of $\mathrm{CH}_{4}$ and $\mathrm{CO}_{2}$ from double rice cropping systems under varying tillage and seeding methods. - Atmospheric Environment 80: 438-444.

[21] Liu, C., et al. (2010): Nitrous oxide and nitric oxide emissions from an irrigated cotton field in Northern China. - Plant and Soil 332: 123-134.

[22] Liu, Q., et al. (2019): Biochar application as a tool to decrease soil nitrogen losses $\left(\mathrm{NH}_{3}\right.$ volatilization, $\mathrm{N}_{2} \mathrm{O}$ emissions, and $\mathrm{N}$ leaching) from croplands: Options and mitigation strength in a global perspective. - Global Change Biology 25: 2077-2093.

[23] Mehmood, F., et al. (2019): Nitrous oxide emission from winter wheat field as responded to irrigation scheduling and irrigation methods in the North China Plain. - Agricultural Water Management 222: 367-374.

[24] Meng, W. W., et al. (2016): Effects of different maize/peanut intercropping modes on system yield and land equivalent ratio. - Shandong Agricultural Sciences 48: 32-36.

[25] Nath, C. P., et al. (2017): Greenhouse gases emission, soil organic carbon and wheat yield as affected by tillage systems and nitrogen management practices. - Archives of Agronomy and Soil Science 63: 1644-1660.

[26] Pappa, V. A., et al. (2011): Nitrous oxide emissions and nitrate leaching in an arable rotation resulting from the presence of an intercrop. - Agriculture, Ecosystems \& Environment 141: 153-161.

[27] Perdomo, C., et al. (2009): Nitrous oxide emissions from an Uruguayan argiudoll under different tillage and rotation treatments. - Nutrient Cycling in Agroecosystems 84: 119128.

[28] Qiu, W., et al. (2019): Physiological and molecular mechanisms of improved iron nutrition of peanut intercropping with maize. - Chinese Science Bulletin 64: 1129-1136.

[29] Scheer, C., et al. (2008): Nitrous oxide emissions from fertilized, irrigated cotton (Gossypium hirsutum L.) in the Aral Sea Basin, Uzbekistan: influence of nitrogen applications and irrigation practices. - Soil Biology and Biochemistry 40: 290-301.

[30] Senbayram, M., et al. (2016): Legume-based mixed intercropping systems may lower agricultural born $\mathrm{N}_{2} \mathrm{O}$ emissions. - Energy, Sustainability and Society. https://doi.org/10.1186/s13705-015-0067-3.

[31] Seran, T. H., Brintha, I., (2010): Review on maize based intercropping. - Journal of agronomy 9: 135-145.

[32] Si, Z., et al. (2020): Effects of nitrogen application rate and irrigation regime on growth, yield, and water-nitrogen use efficiency of drip-irrigated winter wheat in the North China Plain. - Agricultural Water Management 231: 106002.

[33] Simojoki, A., Jaakkola, A., (2000): Effect of nitrogen fertilization, cropping and irrigation on soil air composition and nitrous oxide emission in a loamy clay. - European Journal of Soil Science 51: 413-424. 
[34] Smith, K. A., et al. (2003): Exchange of greenhouse gases between soil and atmosphere: interactions of soil physical factors and biological processes. - European Journal of Soil Science 54: 779-791.

[35] Stocker, T. F., et al. (2013): Technical Summary. Climate Change 2013: The Physical Science Basis. - Contribution of Working Group I to the Fifth Assessment Report of the Intergovernmental Panel on Climate Change. Cambridge University Press, Cambridge, pp 33-115.

[36] Subbarao, G. V., et al. (2012): Biological nitrification inhibition a novel strategy to regulate nitrification in agricultural systems. - Advances in Agronomy 114: 249-302.

[37] Tang, Y. L., et al. (2016): Effects of intercropping on soil $\mathrm{CO}_{2}$ and $\mathrm{N}_{2} \mathrm{O}$ emissions from upland: a review. - Ying yong sheng tai xue bao $=$ The Journal of Applied Ecology 27: 1323-1330.

[38] Vachon, K. (2008): Soil carbon and nitrogen dynamics and greenhouse gas mitigation in intercrop agroecosystems in Balcarce, Argentina. - A thesis presented to the University of Waterloo in fulfillment of the thesis requirement for the degree of Master of Environmental Studies in Environment and Resource Studies.

[39] Vejan, P., et al. (2016): Role of plant growth promoting rhizobacteria in agricultural sustainability-a review. - Molecules 21: 573.

[40] Wang, J. (2015): Reciprocity of Iron and Nitrogen and Its Mycorthizal Effect in the Maize/Peanut Intercropping System. - Henan University of Science and Technology, Luoyang (in Chinese).

[41] Wunderlin, P., et al. (2012): Mechanisms of $\mathrm{N}_{2} \mathrm{O}$ production in biological wastewater treatment under nitrifying and denitrifying conditions. - Water Research 46: 1027-1037.

[42] Xie, J.-f., Li, Y.-e., (2005): Effect of soil temperature on $\mathrm{N}_{2} \mathrm{O}$ emission in upland farm of Beijing. - Chinese Journal of Agrometeorology 26: 7-10.

[43] Yong, T.-W., et al. (2018): Optimized nitrogen application methods to improve nitrogen use efficiency and nodule nitrogen fixation in a maize-soybean relay intercropping system. - Journal of Integrative Agriculture 17: 664-676.

[44] Yu, L., et al. (2019): Nitrogen-cycling genes and rhizosphere microbial community with reduced nitrogen application in maize/soybean strip intercropping. - Nutrient Cycling in Agroecosystems 113: 35-49.

[45] Zhao, Z., et al. (2017): Nitrification inhibitor's effect on mitigating $\mathrm{N}_{2} \mathrm{O}$ emissions was weakened by urease inhibitor in calcareous soils. - Atmospheric Environment 166: 142150. 